\title{
Obituary Notice of Joseph Decaisne, Member of the Institute of France, Honorary Fellow
}

\section{Andrew Taylor}

To cite this article: Andrew Taylor (1883) Obituary Notice of Joseph Decaisne, Member of the Institute of France, Honorary Fellow, Transactions of the Botanical Society of Edinburgh, 14:1-4, 295-297, DOI: 10.1080/03746608309468417

To link to this article: http://dx.doi.org/10.1080/03746608309468417

曲 Published online: 01 Dec 2010.

Submit your article to this journal $\pi$

Џll Article views: 2

Q View related articles $\sqsubset$ 
On the Physical Aspect of the Punjab, its J Jour. A. H. Soc. Ind., viii. Agriculture and Botany. 1854.

On the Cultivation of Tea in the District of Kangra. April 1854.

Papers on the Tea Factories and Plantations in Kemaon and Gurhwal. May 1854.

On the Culture of Flax in the North-West

Provinces for the sake of its Fibre. Jan. 1855.

Papers regarding the Cultivation of Hemp in India. March 1855.

Report of Botanical Gardens of the Government North-Western Provinces. 4to, p. 429. 1855.

Report on the Present State and Future Prospects of Tea Cultivation in the NorthWestern Provinces and Punjab. Calcutta, 1857.

Correspondence regarding Tea Plantations in the Punjab Provinces. Lahore, 1859.

Correspondence respecting the Cultivation of Flax in the North-West Provinces. 1861.

Letter to Professor Balfour, dated Saharunpore. July $9,1863$.

App. 162.

Ed. N. Phil. Jour., lvii. 76.

Agra. (Published by Government.)

Jour. A. H. Soc. Ind., ix. App. 31.

Agra. (Published by Government.)

Roorkee

Government of India Records (Home Dept.), No. xxiii.

Selections from the Correspondence of the Punjab Government, vol. iv., No. 2.

Jour. A. H. Soc. Ind., xi. 597.

Bot. Soc. Trans., viii. 66 .

\section{Obituary Notice of Joseph Decaisne, Member of the Institute of France, Honorary Fellow. By Andrew Taylor.}

(Read 8th June 1882.)

Joseph Decaisnse died on the 8th February 1882, aged 73. He was a native of Brussels, the celebrated Charles Morren being his playmate. Both were eager butterfly hunters as children; both, when men, became leaders in horticulture, one in France, the other in Belgium. He entered the Jardin des Plantes at the age of seventeen, and gradually worked his way up till he succeeded Mirbel as Professor de Culture and Director of the Garden. A working gardener in the department of the Museum in 1821, M. Decaisne was elected President of the Academy of Sciences in 1864, and a Member of the Royal Society of London in 1880. He was enrolled in our list in 1867.*

Decaisne's attachment to his beloved Jardin des Plantes was a life passion; and there, of course, we look for the results of his long studies. He managed this establishment, not on the idea of its being a public recreation ground for tired city holiday seekers, but rather as a 377.

* A portrait and notice of his labours are in Gardener's Chronicle, 1871, P.

TRANS. BOT. SOO. VOL. XIV. 
working place for earnest students. Some of the members of our Society can testify to his individual courtesy, which was always available, whether to obscure students of theoretic botany or poor peasant farmers troubled by pomological puzzles. Even the terrible siege of Paris in 1870-71 did not drive the Director from his post. $\mathrm{He}$ wrote to Dr Masters in 1871, when in January over eighty shells had fallen within the precinets of the garden, how the Pandanus, the Cyclanths, and the Dracænas had their leaves torn to ribbons, while the Bromeliads were not only uninjured by the explosions, but were not hurt by the frost which destroyed so many nearly allied plants. And for ten years after this terrible ordeal, Decaisne managed his great Institution with more activity than many a younger man accustomed only to the fair side of life.

His printed works also kept pace with his administrative energy. The English reader knows Sir Joseph Hooker's translation of his beautifully illustrated conjunct Traité generale de Botanique, 1868 ; and further proof of his systematic work may be found in various monographs in De Candolle's Prodromus, in the Revue Horticole, or in the Annales des Sciences Naturelles, of the botanical department of which he was long joint editor. Decaisne, probably incited by his Herbarium work, early published Florula Sinaica (Paris, 1834) from plants collected by Bové, and Plantes de la Arabie Heureuse (Botta, Paris, 1841). From such studies, Decaisne turned to Algology, and may be ranked as its founder in the sense patent to our physiological laboratories. He studied, along with his friend Thuret, Fuci originally obtained in the Paris fish market, though afterwards at the sea-coast. In a joint paper, published in 1844, the relations involved in the fertilisation of Fucus vesiculosus, bladder wrack, were first made clear; the common coraline of our shores was also shown to be not a polype, but a seaweed. This morphological method of study soon influenced his horticultural studies, the summation of which will be found in Le Jardin Fruitier du Musenm, with its splendidly coloured plates. There, the so-called calyx tube of the Pomacee, the eatable portion of the apple and pear, is shown to be really the top of the flower stalk rendered swollen and succulent. Decaisne, however, believed in the 
existence of genera and species, as understood in preDarwinian days, and in their limitation by definite, though extremely wide and elastic, boundaries. He did not make every variation a distinct species. He held that the countless varieties of pears, apples, strawberries, and the like, all proceeded from a few original forms. But he had no faith in the alleged transformation of the wild radish, carrot, or cabbage into the cultivated varieties. He held strongly that nature acts in the fields as she does in the garden. Yet with him the apple (Malus) and the pear (Pyrus) were two absolutely distinct genera; botanists who, after Linnæus, combine the two, contradict the direct teachings of nature. Mr Thistleton Dyer says Decaisne's turn of mind was essentially precise and matter of fact. He would triumphantly show crops of a cruciferous plant raised in front of the physiological laboratory under wire gauze for many successive years. There is no departure he would say, so far from the specific type, and beyond this kind of evidence he did not seem to care to go.

Altogether Decaisne stands out a typical man in botany, a combination we have more frequently seen in the engineering profession, embodying all the best qualities of the savan and the owvrier.

M. Pierre Decaisne, Honorary Inspector-General du Service de Santé of the Belgian army, has given to the State Botanic Garden at Brussels his brother Joseph Decaisne's herbarium, manuscripts, and drawings. Among: the manuscripts is one of Tournefort given to Decaisne by his friend G. Thuret, and another by A. L. de Jussieu, picked up for a franc at a Paris bookstall. Decaisne's botanical correspondence, with part of Riocreux's drawings, are given to the Library of the Institute; the rest of these inimitable illustrations being a bequest to the National Library.

The foreign necrology for the past year includes the names of Schleiden, an Honorary Fellow, and of Rabenhorst and Hildebrandt, Foreign and Corresponding Members.

Matthius JаKob Schleiden was born on 5th April 1804 at Hamburg, and died at Frankfurt am Main on 23rd June 1881, having lived to see his cell theory mark an 